\title{
Long-term Deflections in Balanced Cantilever Prestressed Concrete Bridges
}

\author{
Eltayeb Hassan Onsa ${ }^{1}$, Elsafi Mohamed Adam², \\ Abdalla Khogali Ahmed ${ }^{3}$, and Mohamed Elmontasir Elbagir ${ }^{4}$
}

\section{Abstract}

Long-term deflections in balanced cantilever prestressed concrete bridges are reviewed. Burri and Shambat Bridges are taken as cases study to calculate long-term deflection. The two bridges were constructed at Khartoum State in the years 1972 and 1962, respectively. Due to the shortage of the basic data regarding the two bridges the AASHTO-LRFD is used to estimate and calculate the missing data in the two bridges.

The Moment Area method is used to calculate the long-term deflections due to the dead load, live load and prestressing force. The calculated long-term deflections are compared with measured live load deflections obtained from load tests made by a Chinese contractor requested to evaluate the two bridges.

Remarkable differences between theoretical and measured deflection at the end of cantilevers are encountered. The differences are probably due to the basic assumptions made in the formulations of deflection calculations. Some adjustments in the long-term deflection formulae are suggested to bring the calculated deflections in compatibility with measured ones.
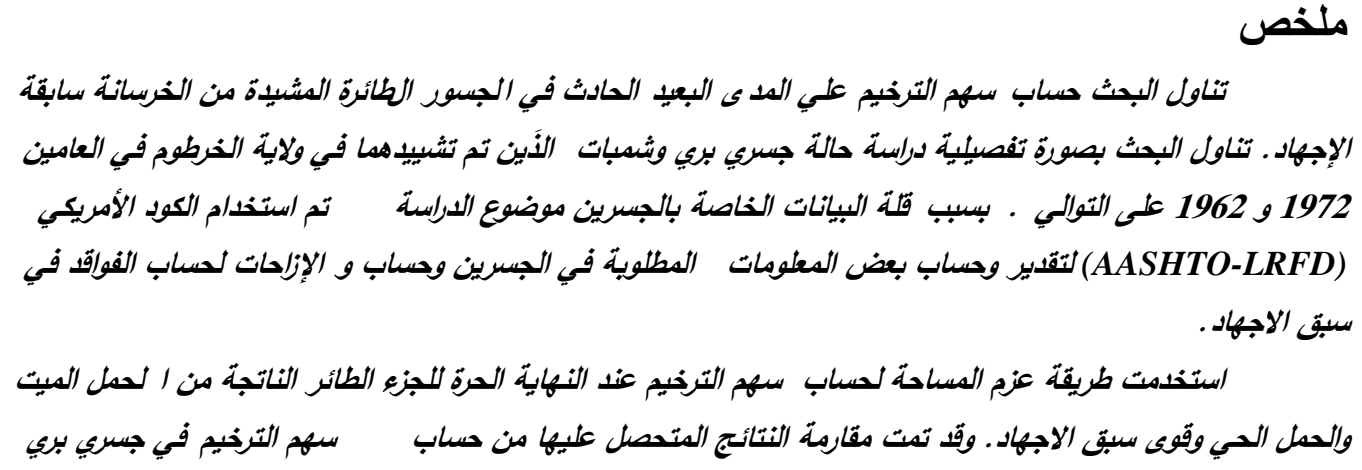

\footnotetext{
${ }^{1}$ Faculty of Eng. Sciences, Omdurman Islamic University, E-mail: eonsah@gmail.com.

${ }^{2}$ Nyala Technical Collage. E-mail: safi_boss12@yahoo.com.

${ }^{3}$ Faculty of Engineering, University of Khartoum, E-mail: akhogali@yahoo.com.

${ }^{4}$ Technocon Consultance Group, E-mail: montasirelbagir@gmail.com.
} 


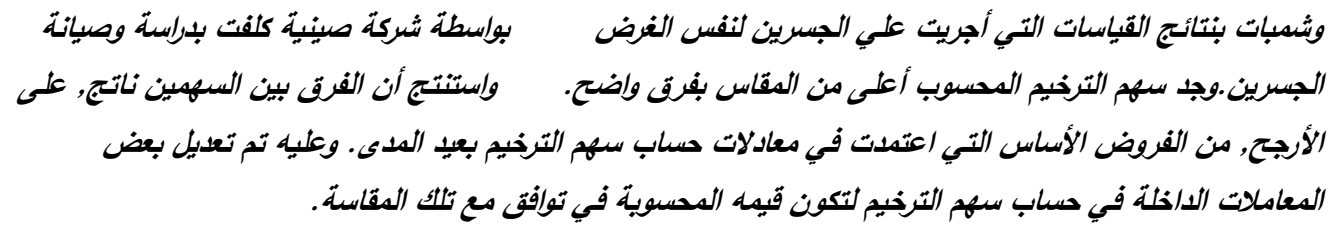

\section{Introduction}

Concrete cantilever bridges built with the balanced cantilever method have become very popular due to the many advantages offered by the construction method and the structural form. Segmentally-cast cantilever bridges often exhibit larger deflections than it was predicted in the design calculation. The excessive deflection can lead to the deterioration of the aesthetic of the bridge and may reach the level where serviceability and traffic safety are compromised. The many cases where long-term deflections significantly exceeded the expected deflections have made design engineers and researchers beware of the deformation problem in this type of structure.

Deflections of the superstructure are large due to the slender and long free concrete span and the fact that the permanent loads are only partially compensated by the prestressing.

The deformations are increasing with time over the entire life span of the bridge, although in a decreasing rate. The physical mechanisms which are responsible for the time dependent deformation increase in concrete are creep and shrinkage, where the former is stress dependent and the latter is stress independent.

\section{Problem Statement}

In this research Burri and Shambat Bridges were taken as case studies to calculate the long-term deflections and compare them with measured deflection. The problem is raised nowadays because of the excessive deflection at the end of the cantilevers of the main bridge. These deflections occurred due to the loss of prestressing force due to the creep of concrete and the relaxation of the prestressing steel tendons. 
مجلة العلوم الهندسية_ العدد الرابعـ 2009

\section{Objectives}

This research aims at calculating the long-term deflections in balanced cantilever prestressed concrete bridges in accordance with the AASHTOLRFD, and compares the calculated deflection with measured deflections due to live load. Suggestions to modify the exultant formulae for long-term deflection will be presented.

\section{Methodology:}

There are many methods which can be used in calculating long-term deflection, such as incremental time-steps method which is based on combining the computation of deflection with those of pre-stress losses due to timedependant creep, shrinkage, and relaxation, and approximate time-step method which is based on simplified form of summation of constituent deflection due to various time-dependent method factors. This is done in addition to the moment area method which is used in calculating the long-term deflections.

\section{Burri Bridge}

\subsection{Bridge Description}

Burri Bridge was constructed on the Blue Nile River at Khartoum in the year 1972. It is a perpetual bridge built with reinforced concrete with diversified applications. The balanced cantilever part of the bridge is composed of six segments carried on six piers; Fig.1 shows the dimensions of a typical segment. The balanced cantilever box beams consist of double boxes with single chamber. The width of the bridge deck is $22.82 \mathrm{~m}$, and the bottom width of single box is $5.14 \mathrm{~m}$. The height of the beam changes from $5 \mathrm{~m}$ at the root of the cantilever to $1.6 \mathrm{~m}$ at the end of the cantilever.

The concrete box section has 120 bundles of prestressing steel tendons, each bundle is composed of 12D12.7, single strands $12 \varphi 12$ and the nominal area of the single strand is $92.9 \mathrm{~mm}^{2[2,10]}$. 


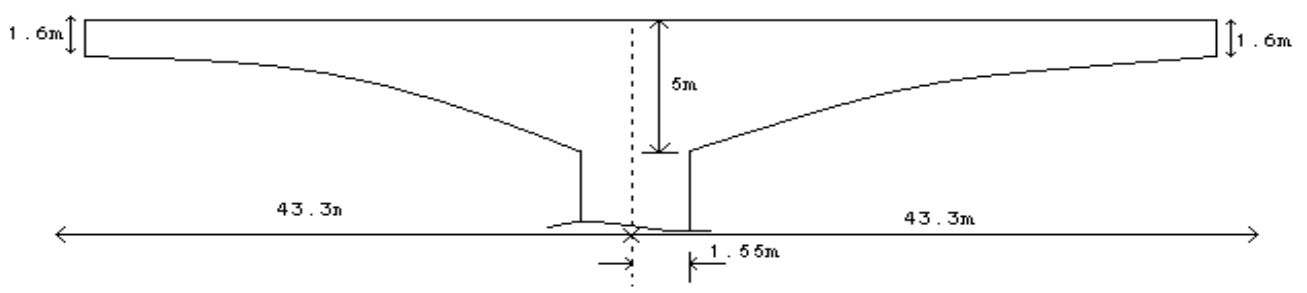

Figure 1: Typical balanced cantilever segment in Burri Bridge

\subsection{Material Properties of the Concrete Deck Section}

i. Prestressing steel: The ultimate breaking strength of prestressing steel, $f_{p u}=1,725 \mathrm{MPa}$

ii. Modulus of elasticity of prestressing: According to the AASHTOLRFD the modulus of elasticity of prestressing steel can be taken as: $E_{p}=19,700 \mathrm{MPa}$

iii. Concrete compressive strength: According to the Chinese test report, the compressive strength of the main bridge was predicated, using Schmitt Hammer Test, to be 47.4 MPa after 30 year of service ${ }^{[9,10]}$. The concrete strength at transfer is estimated to be $34.0 \mathrm{MPa}$ (cube strength) base on a footnote on drawing No. 5611, BNB-45 July $1967^{[1]}$.

The design concrete strength at 28 days can be estimated by the following equation (ACI 2009) ${ }^{[8]}$ :

$$
\left(f_{c}^{\prime}\right)_{t}=\frac{t}{A+B t} \times\left(f_{c}^{\prime}\right)_{28}
$$

Where:

$t=$ the age of concrete in days

$\left(f^{\prime}\right)_{t}=$ Concrete compressive strength at $t$ days

$A, B$ are a functions of the type of cement used and type of curing employed. Values of $A=4.0$ and $B=0.85$ are obtained from ACI 2009 equation parameters for estimating concrete strength for moist curing and normal strength.

$\left(f^{\prime}\right)_{30 \text { years }}=\left(f^{\prime}\right)_{10800 \text { days }}=47.4 \mathrm{MPa}$ 
Therefore, from equation $(1),\left(f^{\prime}\right)_{28}=47.4 / 1.176=40.3 \mathrm{MPa}$, say $=40 \mathrm{MPa}$ for Burri Bridge.

The modulus of elasticity of concrete is computed by the following equation ${ }^{[11]}$ :

$$
E_{c}=\gamma_{c}^{1.5} \times \sqrt{f_{c l}}
$$

Where:

$\gamma_{c}=$ unit weight of concrete $\left(\mathrm{kg} / \mathrm{m}^{3}\right)$ assumed $=24.0 \mathrm{kN} / \mathrm{m}^{3}$

$f_{c l}=$ cylinder specified strength of concrete $(\mathrm{MPa})=0.8 f_{c u}$

$f_{c u}=$ specified cube strength of concrete $(\mathrm{MPa})$

For transfer conditions: $f_{c l}=0.8 \times 34.0=27.2 \mathrm{MPa}$

and $E_{c i}=4800 \times \sqrt{27.2}=25033.7 \mathrm{MPa}$

for the design strength; $f_{c l}=0.8 \times 40.0=32.0 \mathrm{MPa}$

$$
E_{c}=4800 \sqrt{32.0}=27152.9 \mathrm{MPa}
$$

\subsection{Cross Section Properties}

The actual dimensions of the cantilever span of Burri Bridge ${ }^{[2,10]}$ are shown in Fig. 2. The total cross sectional area at various locations can be determined by summing the following subareas depending on the approximate bridge section shown in Fig.3:

$$
\begin{aligned}
& \operatorname{area}_{1}=6.90 \mathrm{~m}^{2}, \text { area }_{2}=0.84 \mathrm{~m}^{2}, \text { area }_{3}=0.27 \mathrm{~m}^{2}, \text { area }_{4}=0.04 \mathrm{~m}^{2}, \text { area }_{5}=3.47 \mathrm{~m}^{2} \text {, } \\
& \text { area }_{6}=2.08 \mathrm{~m}^{2} \text {, and area } 7=0.4 \times 4 \times y=1.6 y \mathrm{~m}^{2}
\end{aligned}
$$

The total cross sectional area, $A_{T}$, in square meters, is therefore

$$
A_{T}=\Sigma A_{i}=13.60+1.6 y
$$

Where:

$y=$ the depth of the variable part of the section, in meters, determined according to the following equation, assuming parabolic variation of cantilever depth,

$y=3.40-0.1629 x+0.00196 x^{2}$

Where $x$ denotes distance from support centerline. Values of $x$ are calculated at $4 \mathrm{~m}$ length intervals starting from the pier centerline, see Table 3. 


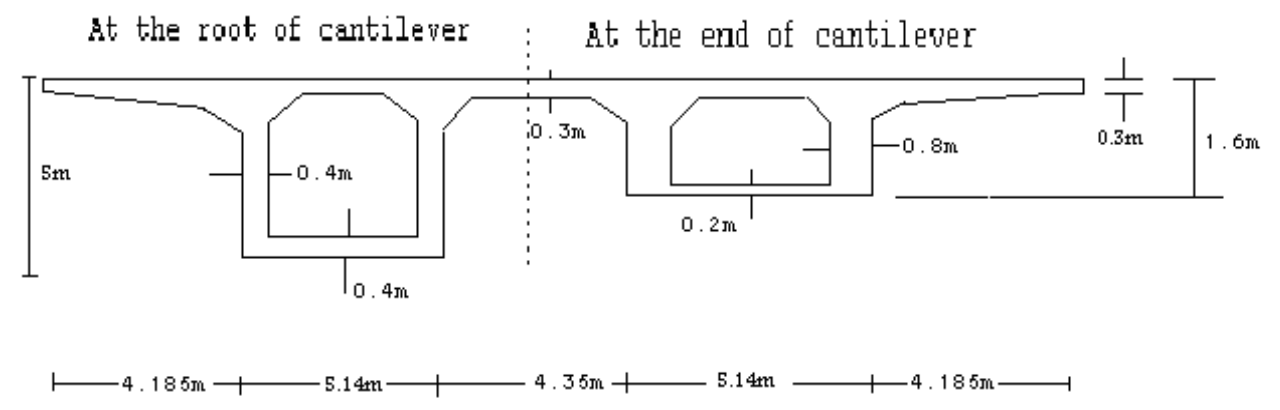

Figure 2: Actual cross section at the root and the end of cantilever - Burri Bridge

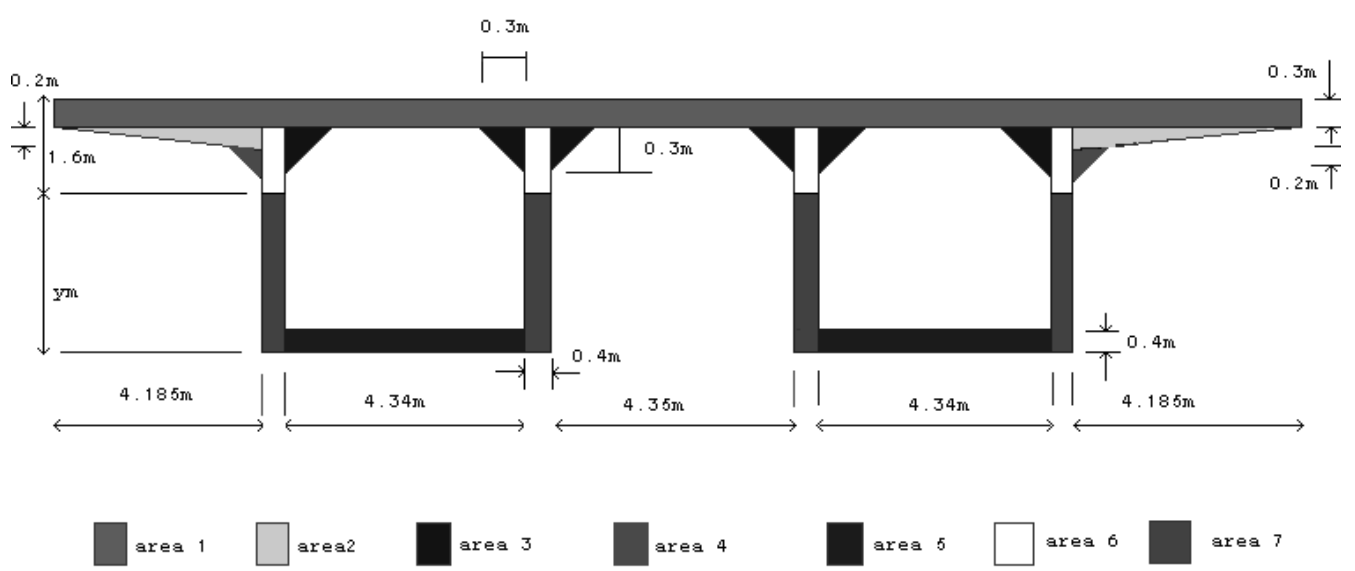

Figure 3: Approximated cross section for area calculation - Burri Bridge

Similarly, the moment of inertia of the cross-section is calculated considering the approximated section shown in Fig.4. 
مجلة العلوم الهندسيةـ العدد الرابع- 2009

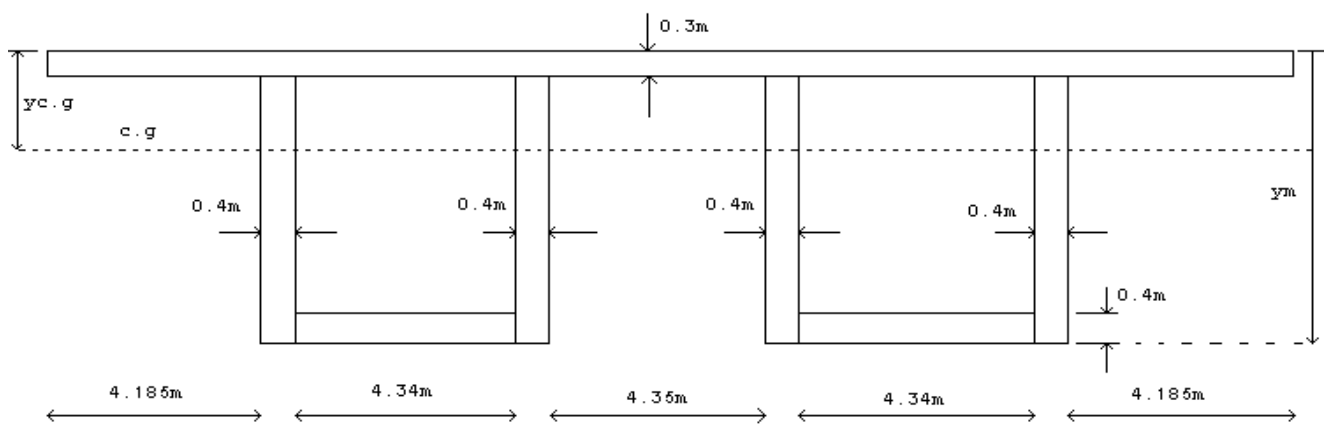

Figure 4: Approximated cross section for moment of inertia calculation - Burri

\section{Bridge}

\subsection{Prestress Losses}

According to the AASHTO-LRFD, the total prestress losses in posttensioned members in single stage can be taken as follows:

$$
\Delta f_{p} T=\Delta f_{p} F+\Delta f_{p} A+\Delta f_{p} E S+\Delta f_{p} S R+\Delta f_{p} C R+\Delta f_{p} R_{2}
$$
in which

$\Delta f_{p} T=$ total loss of prestress

$\Delta f_{p} F=$ loss due to friction

$\triangle f_{p} A=$ loss due to anchorage set

$\Delta f_{p} E S=$ loss due to shortening

$\triangle f_{p} S R=$ loss due to shrinkage

$\triangle f_{p} C R=$ loss due to creep

$\Delta f_{p} R_{2}=$ loss due to relaxation of steel

\subsubsection{Losses due to Anchorage:}

According to AASHTO-LRFD, the anchorage set may be varying between $3 \mathrm{~mm}$ and $10 \mathrm{~mm}$ depending on the type of equipment used. The $6 \mathrm{~mm}$ anchorage set value is often assumed in elongation computations. The general formula for anchorage set in MPa is:

$$
\Delta f_{p} A=\Delta a \frac{E_{p}}{L}=6 \times \frac{197000}{L}
$$

Where: 
$\Delta a=$ anchorage deformation (assumed $=6 \mathrm{~mm}$ )

$L=$ length of tendon, $\mathrm{mm}$.

Each balanced cantilever part of Burri Bridge was prestressed by 12 sets of tendons. Tendons layout vary in length and path profile. The loss due to anchorage is calculated for each group of tendons, the result is summarized in Table 1.

From the values in Table 1 an average value of anchorage set is $=\mathbf{5 8 . 6 4} \mathbf{M P a}$.

\subsubsection{Losses due to Elastic Shortening}

According to AASHTO-LRFD the loss due to the elastic shortening in post-tensioned members can be taken as:

$$
\Delta f_{p} E S=\frac{N-1}{2 N} \times \frac{E_{p}}{E_{c i}} \times f_{c y p}
$$

Where:

$N=$ number of identical prestressing tendons, $=12$ for Burri Bridge,

$f_{c y p}=$ sum of concrete stresses of the center of gravity of prestressing tendons due to prestressing force after jacking and the self weight of the member at the section of maximum moment.

Table 1: Anchorage set of Burri Bridge

\begin{tabular}{|c|c|c|}
\hline $\begin{array}{c}\text { No. of tendons } \\
\text { group }\end{array}$ & $\begin{array}{c}\text { Tendons length } \\
(\mathbf{m})\end{array}$ & $\begin{array}{c}\text { Anchorage set } \\
\text { (MPa) }\end{array}$ \\
\hline 1 & 10.3 & 114.76 \\
\hline 2 & 12.3 & 96.10 \\
\hline 3 & 15.0 & 78.80 \\
\hline 4 & 16.3 & 72.50 \\
\hline 5 & 18.0 & 65.67 \\
\hline 6 & 20.0 & 59.10 \\
\hline 7 & 22.3 & 53.00 \\
\hline 8 & 24.0 & 49.30 \\
\hline 9 & 29.0 & 40.70 \\
\hline 10 & 36.0 & 32.80 \\
\hline 11 & 43.3 & 27.30 \\
\hline 12 & 86.6 & 13.60 \\
\hline
\end{tabular}


The value of $\Delta f_{p} E S$ can be calculated using the following equation ${ }^{[11]}$ :

$$
\Delta f_{p} E S=\frac{N-1}{2 N} \times \frac{A_{p s} f_{p b t}\left(I_{g}+e_{m}{ }^{2} A_{g}\right)-e_{m} M_{g} A_{g}}{A_{p s}\left(I_{g}+e_{m}{ }^{2} A_{g}\right)+A_{g} I_{g} E_{c i} / E_{p}}
$$

Where:

$$
\begin{aligned}
A_{p s} & =\text { area of prestressing steel }=12 \times 92.9 \times 120=133,776 \mathrm{~mm}^{2} \\
A_{g} & =\text { gross area of the section }=18.91 \mathrm{~m}^{2} \\
e_{m} & =\text { average eccentricity at mid span }=739.19 \mathrm{~mm} \\
f_{p b t} & =\text { stress in prestressing steel immediately prior to transfer } \\
& \left.=0.7 f_{p u}=1,207.5 \mathrm{MPa} \text { (From AASHTO- LRFD, Table } 5.9 .3-1\right) \\
I_{g} & =\text { moment of inertia of gross concrete section }=67.79 \times 10^{12} \mathrm{~mm}^{4} \\
M_{g} & =\text { moment at root of cantilever due to the self weight }=3.22 \times 10^{11} \\
\text { N.mm } & \\
E_{p} & =197,000 \mathrm{~N} / \mathrm{mm}^{2}, E_{c i}=25,033.74 \mathrm{~N} / \mathrm{mm}^{2} .
\end{aligned}
$$

Therefore,

$$
\Delta f_{p} E S=31.64 \mathrm{MPa}
$$

\subsubsection{Losses due to Friction}

According to AASHTO-LRFD, article 5.9.5.2.2, the load due to the friction between tendons and the ducts may be taken as:

$$
\Delta f_{p} F=f_{p j} \times\left\lfloor e^{-(k x+\mu \alpha)}\right\rfloor
$$

Where:

$f_{p j}=$ stress in prestressing steel at jacking

$=0.8 f_{p u}$ (from AASHTO-LRFD article 5.9.5.4.4b)

$x=$ length of prestressing tendon from the jacking end to any point under consideration

$k=$ wobble friction coefficient

$\mu=$ coefficient of friction

$\alpha=$ sum of absolute value of angular changes of prestressing steel path from the near jacking end to the point under investigation (in radians) 
The values $k$ and $\mu$ based on experimented data for material specified from Table (5.2.2b-1) AASHTO-LRFD, for the type of duct, rigid or semi-rigid metal sheathing

$$
\begin{aligned}
& k=6.6 \times 10^{-7} \text { per mm } \\
& \mu=0.15 \text { to } 0.25,(\text { taken }=0.25)
\end{aligned}
$$

The value of $\alpha$ was computed according to the tendon layout, taking

The maximum friction loss $=148.2 \mathrm{MPa}$, for longest cables;

The minimum friction loss $=18.64 \mathrm{MPa}$, for shortest cables;

The average friction loss is, therefore, $\Delta f_{p} F=65.78 \mathrm{MPa}$

The time dependant losses are creep, shrinkage of the concrete and steel relaxation. An approximate estimate of time dependent prestress losses is made as follows:

\subsubsection{Losses due to Shrinkage}

The losses of prestressing due to shrinkage for post-tensioned members can be taken as ${ }^{[11]}$ :

$$
\Delta f_{p} S R=93-0.85 H
$$

Taking the average relative humidity, $H,=29 \%$ for Khartoum will result in

$$
\Delta f_{p} S R=68.35 \mathrm{MPa}
$$

\subsubsection{Losses due to Creep}

According to AASHTO-LRFD, the prestress loss due to creep is given by:

$$
\Delta f_{p} C R=12.0 f_{c g p}-7.0 \Delta f_{c d p}>0.0
$$

Where:

$f_{c g p}=$ concrete stress at center of gravity of prestressing steel at transfer (MPa)

$\Delta f_{c d p}=$ change of concrete stress at center of gravity of prestressing steel due to permanent loads with the exception of the load acting at the time the prestressing force is applied

$$
f_{c g p}=\frac{f_{p t} \times A_{p s}}{A_{g}}+\frac{f_{p t} \times A_{p s} \times e_{m}{ }^{2}}{I_{g}}-\frac{e_{m} \times M_{g}}{I_{g}}
$$


In which

$$
f_{p t}=f_{p b t}-\Delta f_{p} A-\Delta f_{p} E S
$$

Substitute to get $f_{c g p}=4.58 \mathrm{MPa}$

The additional permanent loads resulted from the asphalt layer and the sidewalks slabs, assuming asphalt layer thickness $=70 \mathrm{~mm}$ and the sidewalks slab thickness $=120 \mathrm{~mm}$, is found to be $=43.26 \mathrm{kN} / \mathrm{m}$. Therefore, the additional bending moment and bending stress will be, respectively:

$$
\begin{gathered}
M_{a d d}=\frac{w l^{2}}{2}=\frac{\left(43.26 \times 41.75^{2}\right) \times 10^{6}}{2}=3.77 \times 10^{10} \mathrm{~N} . \mathrm{mm} \\
f_{c d p}=\frac{M_{a d d} \times e_{m}}{I_{g}}=\frac{3.77 \times 10^{10} \times 739.2}{67.79 \times 10^{12}}=0.41 \mathrm{MPa}
\end{gathered}
$$

Substituting in equation (11) to get

$$
\Delta \boldsymbol{f}_{p} \boldsymbol{C R}=12 \times 4.58-7 \times 0.41=\mathbf{5 2 . 1} \mathbf{M P a} \text {. }
$$

\subsubsection{Losses due to Relaxation of Steel:}

The losses due to relaxation of steel for post-tensioned stress relieved strands conforming to AASHTO-2003, article (5.9.5.4.4c) are given by the following equation:

$\Delta f_{p} R_{2}=138.0-0.3 \Delta f_{p} F-0.4 \Delta f_{p} E S-0.2\left(\Delta f_{p} S R+\Delta f_{p} C R\right)$

Substituting relative values in equation (14) to get $\Delta \boldsymbol{f}_{p} \boldsymbol{R}_{\mathbf{2}}=\mathbf{9 4 . 0} \mathrm{MPa}$

Hence, total loss in prestress can be obtained according to equation (5) by substituting the calculated values of $\Delta f_{p} F, \Delta f_{p} A, \Delta f_{p} E S, \Delta f_{p} S R, \Delta f_{p} C R, \Delta f_{p} R_{2}$ in equation (5) to obtain

$$
\Delta \boldsymbol{f}_{\boldsymbol{p}} \boldsymbol{T}=361.9 \mathrm{MPa}\left(=30 \% \text { of } 0.7 f_{p u}\right)
$$

The effective prestressing force $=$ the initial prestressing force minus the losses. Assuming at transfer, after the elastic shortening and anchorage set, to be $=$ $0.7 f_{p u}$

$$
\therefore f_{p e}=0.7 f_{p u}-\Delta f_{p} T=845.6 \mathrm{MPa} \quad\left(\leq 0.5 f_{p u}=8,625 \mathrm{MPa}\right)
$$

Thus, the sum of time dependent losses is

$$
\Delta f_{p} S R+\Delta f_{p} C R+\Delta f_{p} R_{2}=214.5 \mathrm{MPa}
$$


The losses due to relaxation of steel for post-tensioned low-relaxation strands conforming to AASHTO 2003 is given by $30 \%$ of $\Delta f_{p} R_{2}$.

For low relaxation strand; $\Delta f_{p} R_{2}=28.2 \mathrm{MPa}$, see equation (14)

The total loss of prestress for this case $\Delta f_{p} \boldsymbol{T}=296.1 \mathrm{MPa}\left(=24.5 \%\right.$ of $\left.0.7 f_{p u}\right)$

$$
\begin{aligned}
& F_{p e}=0.7 f_{p u}-\Delta f_{p} A+\Delta f_{p} E S+\Delta f_{p} S R+\Delta f_{p} C R+\Delta f_{p} R_{2}=9,113.9 \mathrm{MPa} \\
& \left(\geq 0.5 f_{p u}=862.5 \mathrm{MPa}\right)
\end{aligned}
$$

The sum of time dependent losses:

$$
\Sigma \Delta f_{p} S R+\Delta f_{p} C R+\Delta f_{p} R_{2}=148.6 \mathrm{MPa}
$$

The creep coefficient is calculated by the following equation, (AASHTO-2005 article 5.4.2.3.2-1):

$$
\Psi\left(t, t_{i}\right)=1.9 k_{v s} k_{h c} k_{f} k_{t d} t_{i}^{-0.118}
$$

See reference [8] for the definitions of $k_{v c}, k_{h c}, k_{f}$, etc.

Table 2 shows the corresponding values of creep coefficient $\Psi$.

Table 2: Values of creep coefficient, result of equation (16)

\begin{tabular}{|c|c|}
\hline Time & Creep coefficient $\boldsymbol{\Psi}$ \\
\hline 6months & 1.24 \\
\hline 1 year & 1.37 \\
\hline 5 years & 1.49 \\
\hline 30 years & 1.52 \\
\hline
\end{tabular}

\subsection{Deflection due to Dead Load}

The self weight, $w$, of the cross section $=\gamma_{c} \times A(\mathrm{kN} / \mathrm{m})$,

$A=$ cross sectional area

$\gamma_{c}=$ weight of the concrete. (For the normal weight concrete $\gamma_{c}=24$ $\mathrm{kN} / \mathrm{m}^{3}$ )

$A=19.04 \mathrm{~m}^{2}$ at the root of the cantilever.

$A=13.6 \mathrm{~m}^{2}$ at the cantilever end.

The weight at the end of cantilever, $w_{1}$, and at the root of cantilever, $w_{2}$, are found to be $w_{1}=24 \times 13.6=326.4 \mathrm{kN} / \mathrm{m}, w_{2}=24 \times 19.04=456.96 \mathrm{kN} / \mathrm{m}$, 


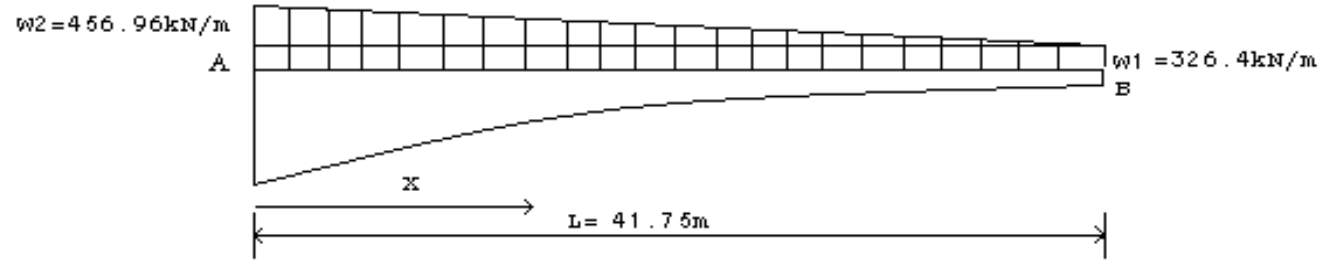

Figure 5: Distribution of self weight along the cantilever of Burri Bridge

The maximum deflection at end of balanced cantilever of Burri Bridge at transfer stage is found to be $\mathbf{8 6 . 4 5} \mathbf{~ m m}$ (downwards). Note that at transfer $E_{c i}=25,033.7 \mathrm{~N} / \mathrm{mm}^{2}$

The effective modulus of elasticity of concrete after 30 years of service live will be given by the following equation;

$$
\begin{aligned}
E_{\text {eff }} & =\frac{E_{c(28 \text { days })}}{\left[1+\Psi\left(t, t_{i}\right)\right]} \\
& =27,152.9 /(1+1.52)=10,775.0 \mathrm{~N} / \mathrm{mm}^{2}
\end{aligned}
$$

Table 3: Calculations of long-term deflections (after 30 years) due to dead load in Burri Bridge,

\begin{tabular}{|c|c|c|c|c|c|c|c|r|}
\hline $\begin{array}{c}\boldsymbol{x} \\
(\mathbf{m})\end{array}$ & $\begin{array}{c}\boldsymbol{y} \\
(\mathbf{m})\end{array}$ & $\begin{array}{c}\text { Area } \\
\left(\mathbf{m}^{\mathbf{2}}\right)\end{array}$ & $\begin{array}{c}\boldsymbol{I} \\
\left(\mathbf{m}^{\mathbf{4}}\right)\end{array}$ & $\begin{array}{c}\text { load } \\
(\mathbf{k N} / \mathbf{m})\end{array}$ & $\begin{array}{c}\boldsymbol{M} \\
(\mathbf{k N . m})\end{array}$ & $\begin{array}{c}\boldsymbol{M} / \boldsymbol{E I} \\
\text { Area }\end{array}$ & $\begin{array}{c}\mathbf{c . g .} \text { of } \\
\boldsymbol{M} / \boldsymbol{E} \mathbf{( \mathbf { m } )})\end{array}$ & $\begin{array}{c}\text { Deflection } \\
(\mathbf{m m})\end{array}$ \\
\hline 0 & 5.00 & 19.040 & 67.79 & 456.96 & $3.25 \mathrm{E}+05$ & 0.0 & 0.00 & 0.00 \\
\hline 4 & 4.38 & 18.048 & 49.56 & 444.45 & $2.60 \mathrm{E}+05$ & $1.86 \mathrm{E}-03$ & $1.97 \mathrm{E}+03$ & 3.67 \\
\hline 8 & 3.82 & 17.155 & 35.90 & 431.94 & $2.04 \mathrm{E}+05$ & $3.89 \mathrm{E}-03$ & $4.06 \mathrm{E}+03$ & 15.78 \\
\hline 12 & 3.33 & 16.362 & 25.81 & 419.43 & $1.56 \mathrm{E}+05$ & $6.06 \mathrm{E}-03$ & $6.18 \mathrm{E}+03$ & 37.45 \\
\hline 16 & 2.89 & 15.669 & 18.50 & 406.93 & $1.15 \mathrm{E}+05$ & $8.33 \mathrm{E}-03$ & $8.31 \mathrm{E}+03$ & 69.20 \\
\hline 20 & 2.52 & 15.076 & 13.29 & 394.42 & $8.08 \mathrm{E}+04$ & $1.06 \mathrm{E}-02$ & $1.04 \mathrm{E}+04$ & 110.24 \\
\hline 24 & 2.21 & 14.583 & 09.67 & 381.91 & $5.32 \mathrm{E}+04$ & $1.28 \mathrm{E}-02$ & $1.24 \mathrm{E}+04$ & 157.57 \\
\hline 28 & 1.97 & 14.190 & 07.23 & 369.40 & $3.16 \mathrm{E}+04$ & $1.46 \mathrm{E}-02$ & $1.41 \mathrm{E}+04$ & 205.34 \\
\hline 32 & 1.79 & 13.897 & 05.66 & 356.89 & $1.58 \mathrm{E}+04$ & $1.59 \mathrm{E}-02$ & $1.54 \mathrm{E}+04$ & 245.42 \\
\hline 36 & 1.66 & 13.703 & 04.09 & 348.36 & $5.47 \mathrm{E}+03$ & $1.67 \mathrm{E}-02$ & $1.63 \mathrm{E}+04$ & 271.66 \\
\hline 40 & 1.61 & 13.610 & 03.72 & 335.85 & $5.06 \mathrm{E}+02$ & $1.70 \mathrm{E}-02$ & $1.66 \mathrm{E}+04$ & 282.22 \\
\hline
\end{tabular}




\begin{tabular}{|l|l|l|l|l|l|l|l|l|}
41.75 & 1.60 & 13.600 & 03.68 & 330.32 & $0.00 \mathrm{E}+00$ & $1.70 \mathrm{E}-02$ & $1.67 \mathrm{E}+04$ & 283.30 \\
\hline
\end{tabular}

Maximum long term deflection $=\mathbf{2 8 3 . 3 0} \mathbf{~ m m}$ (downwards)

\subsection{Deflection due Live Load}

According to AASHTO-LRFD, article 2.5.2.6.2, vehicular live loading, designed HL-93 shall consist of combination of design truck loading and design lane loading. Each design lane shall be occupied by either the design truck or tandem coincident with the lane load where applied. The lane shall be assumed to occupy $3 \mathrm{~m}$ transversely within the design lane.

The design truck is composed of three axle loads, $35 \mathrm{kN}, 145 \mathrm{kN}$ and $145 \mathrm{kN}$, see Fig. 6 (Note that the loads are multiplied by 4, number of design lanes)

Case of all design lanes loaded is considered in the calculations of live load deflection as follows:

(i) When investigating absolute deflection; all design lanes shall be loaded. Single design truck-all lanes loaded, see Fig. 6;

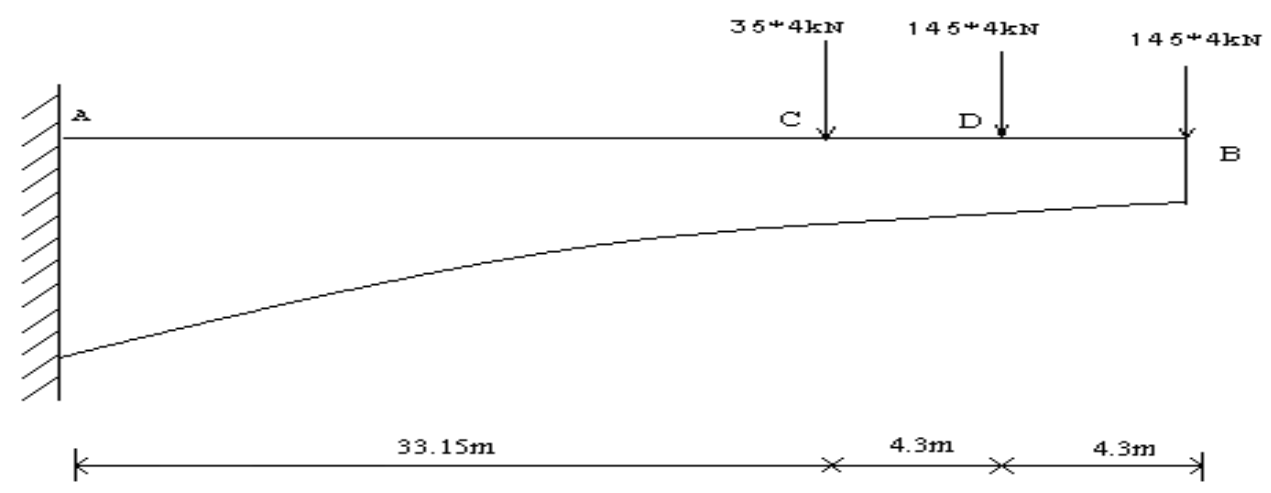

Figure 6: longitudinal loading

(ii) Lane load-all lanes loaded as shown in Fig. 7. 


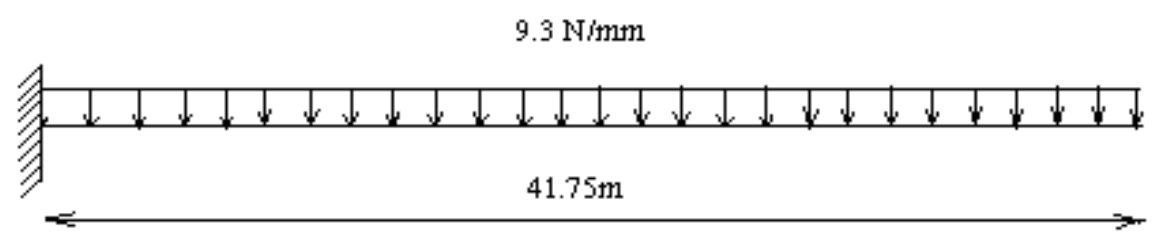

Figure 7: Lane load

Table 4*: Calculations of long-term deflections due to H/Y live load on Burri Bridge $^{[10]}$

\begin{tabular}{|c|c|c|c|c|c|c|c|}
\hline $\begin{array}{c}\mathbf{X} \\
(\mathbf{m})\end{array}$ & $\begin{array}{c}\boldsymbol{y} \\
(\mathbf{m})\end{array}$ & $\begin{array}{c}\text { Area } \\
\left(\mathbf{m}^{2}\right)\end{array}$ & $\begin{array}{c}\boldsymbol{I} \\
\left(\mathbf{m}^{\mathbf{4}}\right)\end{array}$ & $\begin{array}{c}\boldsymbol{M} \\
(\mathbf{k N . m})\end{array}$ & $\begin{array}{c}\boldsymbol{M} / \boldsymbol{E I} \\
\text { Area }\end{array}$ & $\begin{array}{c}\text { c.g. of } \\
\boldsymbol{M} / \boldsymbol{E I}\end{array}$ & $\begin{array}{c}\text { Deflection } \\
(\mathbf{m m})\end{array}$ \\
\hline 0 & 5.00 & 19.040 & 67.79 & 79503.84 & 0 & $0.00 \mathrm{E}+00$ & 0 \\
\hline 8 & 3.82 & 17.155 & 35.90 & 55536 & $1.01 \mathrm{E}-03$ & $4.09 \mathrm{E}+03$ & 4.12 \\
\hline 16 & 2.89 & 15.669 & 18.50 & 39549.12 & $2.35 \mathrm{E}-03$ & $8.67 \mathrm{E}+03$ & 20.38 \\
\hline 24 & 2.21 & 14.583 & 9.67 & 27069.12 & $4.20 \mathrm{E}-03$ & $1.37 \mathrm{E}+04$ & 57.47 \\
\hline 32 & 1.79 & 13.897 & 5.66 & 14589.12 & $6.26 \mathrm{E}-03$ & $1.84 \mathrm{E}+04$ & 115.20 \\
\hline 43.3 & 1.60 & 13.608 & 3.71 & 0 & $7.77 \mathrm{E}-03$ & $2.18 \mathrm{E}+04$ & 169.39 \\
\hline
\end{tabular}

Maximum deflection $=\mathbf{1 6 9 . 3 9} \mathbf{~ m m}$ (downward)

\subsection{Deflection due to Prestressing}

The moment due to prestressing force at each section of cantilever can be computed when the number of tendons and the eccentricity are known as follows:

(i) Initial condition:

$$
M_{p}=F e=\left(f_{p t} \times A \times N\right) \times e
$$

Where:

$$
\begin{aligned}
M_{p} & =\text { moment due to prestressing } \\
A & =\text { tendon area } \\
N & =\text { number of tendons at any section } \\
e & =\text { eccentricity (variable for each section) } \\
f_{p t} & =\text { Prestressing force at transfer, } \\
& =0.7 f_{p u}-\Delta f_{p} E S-\Delta f_{p} A=0.7 \times 1725-23.02-58.64=1125.8 \mathrm{MPa}
\end{aligned}
$$

\footnotetext{
${ }^{*}$ Note that calculations for $x=4,12,20,28,36$, and 40m are omitted in this Table and Tables 5, 6, and 8 .
} 
Long-term Deflections in Balanced Cantilever Prestressed ....

Eltayeb Hassan Onsa

(iii) Table 5 shows the long-term deflections (after 30 years) due to prestressing, note that after 30 years $E_{c}=10,775.0 \mathrm{MPa}$.

Table 5: Calculations of long-term deflections due to prestressing in Burri Bridge (after 30 years)

\begin{tabular}{|c|c|c|c|c|c|c|c|c|}
\hline $\begin{array}{c}\boldsymbol{x} \\
(\mathbf{m})\end{array}$ & $\begin{array}{c}\boldsymbol{y} \\
(\mathbf{m})\end{array}$ & $\begin{array}{c}\text { Area } \\
\left(\mathbf{m}^{\mathbf{2}}\right)\end{array}$ & $\begin{array}{c}\boldsymbol{I} \\
\left(\mathbf{m}^{\mathbf{4}}\right)\end{array}$ & $\boldsymbol{N}$ & $\begin{array}{c}\boldsymbol{e} \\
(\mathbf{m m})\end{array}$ & $\begin{array}{c}\boldsymbol{M} \\
(\mathbf{N} . \mathbf{m m})\end{array}$ & $\begin{array}{c}\boldsymbol{M} / \boldsymbol{E I} \\
\text { Area }\end{array}$ & $\begin{array}{c}\text { Deflection } \\
(\mathbf{m m})\end{array}$ \\
\hline 0 & 5.00 & 19.040 & 67.79 & 120 & 1809.92 & $2.2 \mathrm{E}+11$ & 0 & 0.00 \\
\hline 8 & 3.82 & 17.155 & 35.90 & 112 & 1048.67 & $1.2 \mathrm{E}+11$ & $2.42 \mathrm{E}-03$ & 9.68 \\
\hline 16 & 2.89 & 15.669 & 18.50 & 74 & 765.95 & $5.8 \mathrm{E}+10$ & $4.79 \mathrm{E}-03$ & 38.08 \\
\hline 24 & 2.21 & 14.583 & 9.67 & 55 & 601.45 & $3.4 \mathrm{E}+10$ & $7.15 \mathrm{E}-03$ & 85.51 \\
\hline 32 & 1.79 & 13.897 & 5.66 & 38 & 414.67 & $1.6 \mathrm{E}+10$ & $9.53 \mathrm{E}-03$ & 151.89 \\
\hline 41.75 & 1.60 & 13.600 & 3.68 & 20 & 141.76 & $2.9 \mathrm{E}+09$ & $1.11 \mathrm{E}-02$ & 203.64 \\
\hline
\end{tabular}

Maximum deflection $\mathbf{=} \mathbf{2 0 3 . 6 4} \mathbf{~ m m}$ (upwards)

The preceding deflection results due to dead load, live load, and prestressing load are summarized in Table 6.

Table 6: Final long-term deflections in Burri Bridge (According to AASHTO-LRFD)

\begin{tabular}{|c|c|c|c|c|}
\hline $\begin{array}{c}\text { Distance, } \boldsymbol{x}, \\
\text { from support } \\
(\mathbf{m})\end{array}$ & $\begin{array}{c}\text { Dead load } \\
\text { deflection } \\
(\mathbf{m m})\end{array}$ & $\begin{array}{c}\text { Live load } \\
\text { deflection }(\mathbf{m m})\end{array}$ & $\begin{array}{c}\text { deflection due } \\
\text { to Prestressing } \\
(\mathbf{m m})\end{array}$ & $\begin{array}{c}\text { Total } \\
\text { deflection } \\
(\mathbf{m m})\end{array}$ \\
\hline 0 & -0.0 & 0.0 & 0.00 & 0.00 \\
\hline 8 & -15.78 & -3.69 & +9.68 & -9.78 \\
\hline 16 & -69.20 & -19.59 & +38.08 & -50.72 \\
\hline 24 & -157.57 & -55.00 & +85.51 & -127.06 \\
\hline 32 & -245.42 & -105.59 & +151.89 & -199.12 \\
\hline 41.75 & -283.30 & -142.05 & +203.64 & -221.71 \\
\hline
\end{tabular}

Note: Negative signs indicate downwards deflection. 


\subsection{Loading Test on Burri Bridge:}

Experimental load test was conducted on Burri and Shambat Bridges in the year 2005 by a Chinese Road and Bridge Company contracted by the Ministry of Physical Planning and Public Utilities, Khartoum State. The load test is performed as part of the assessment of the two bridges prior to their maintenance. In the load test, loaded Hino trucks of axel loads shown in Fig. 8 were located at predetermined locations along the cantilever bridge lanes, see Fig. 9. The deflections are measured at four points at the end of cantilever as noted in Fig. 10. The results of deflection measurements are show in Table 7. In the same Table calculated long-term deflection is given for comparison. It is worthwhile mentioning that the live loads adopted in the tests made by the Chinese contractor are equivalent in magnitude and position to HL-93 HY loads considered in the calculations.

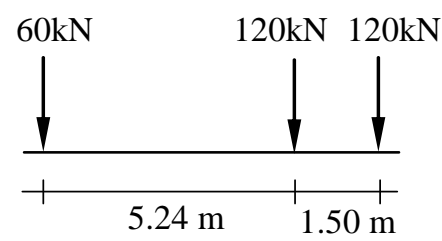

(a)

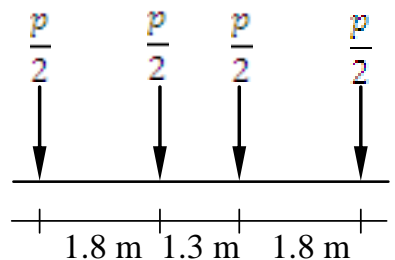

(b)

Figure 8: (a) Longitudinal axel loads of test vehicle, (b) Transverse axel load.

Table 7: Actual measured and calculated deflection values (source: Burri Bridge test report ${ }^{[10]}$ )

\begin{tabular}{|c|c|c|c|}
\hline \multirow{2}{*}{ Cross section } & $\begin{array}{c}\text { Test point, } \\
\text { see Fig.10 }\end{array}$ & $\begin{array}{c}\text { Measured } \\
\text { values (mm) }\end{array}$ & $\begin{array}{c}\text { Calculated value } \\
\text { (mm) }\end{array}$ \\
\hline \multirow{3}{*}{ Cantilever end } & 9 & -231 & \multirow{2}{*}{-210} \\
\cline { 2 - 3 } & 10 & -231 & \multirow{2}{*}{-210} \\
\cline { 2 - 3 } & 11 & -231 & -228 \\
\hline
\end{tabular}




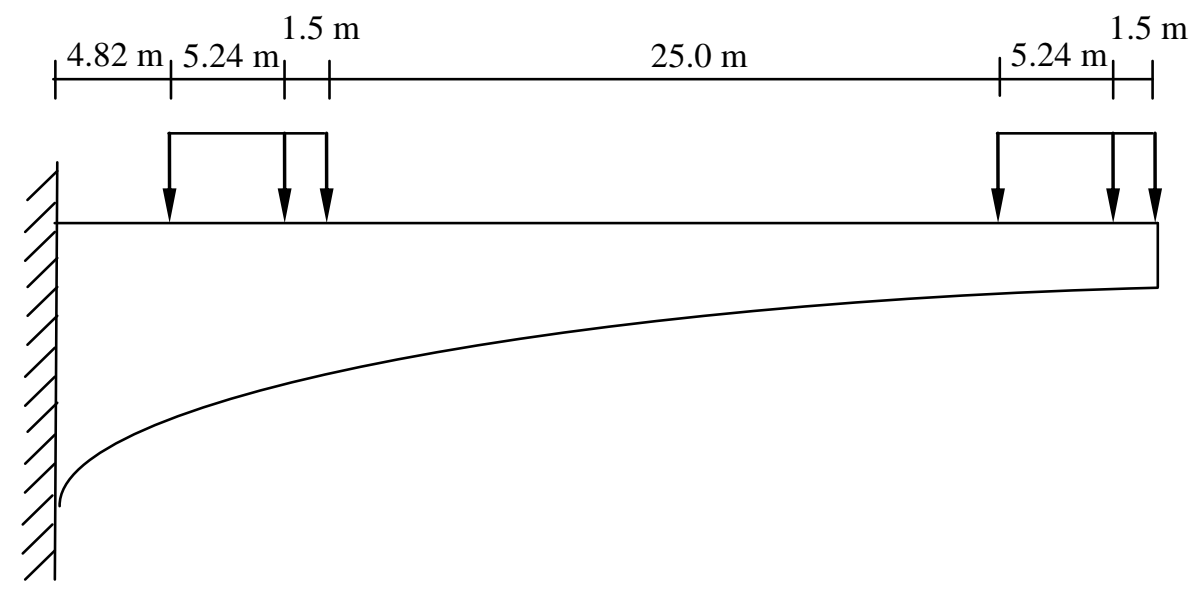

Figure 9: Test Trucks load setup along balanced cantilever of Burri Bridge

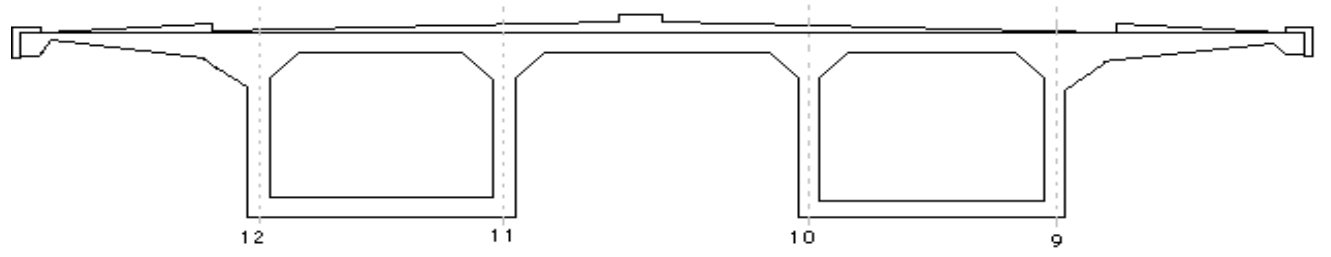

Figure 10: Arrangement of test measurement points at end of cantilever 6. Shambat Bridge

6.1 Bridge Description

Shambat Bridge was built across the River Nile in 1960 to link Khartoum North with Omdurman City. Shambat Bridge is a perpetual bridge built with post-tensioned bonded prestressed concrete and reinforced concrete with diversified applications. The total length of the balanced cantilever part of the bridge is $708.5 \mathrm{~m}$ carried on equidistant 8 piers. Typical balanced cantilever span of Shambat Bridge in shown in Fig. 11. 
The top width of the bridge $22.6 \mathrm{~m}$, and the bottom width of the single box is $5.14 \mathrm{~m}$. The height of the balanced cantilever beam varies from $5 \mathrm{~m}$ at the root of the cantilever to $1.6 \mathrm{~m}$ at its end. The concrete box section of Shambat Bridge is known to have 120 bundles of prestressing steel tendons, each one composed of 12D12.7, single strands $12 \varphi 12$ and the nominal area of the single strand is $92.9 \mathrm{~mm}^{2}$. The tensile strength is estimated to be $1725 \mathrm{MPa}$ based on the year of construction.

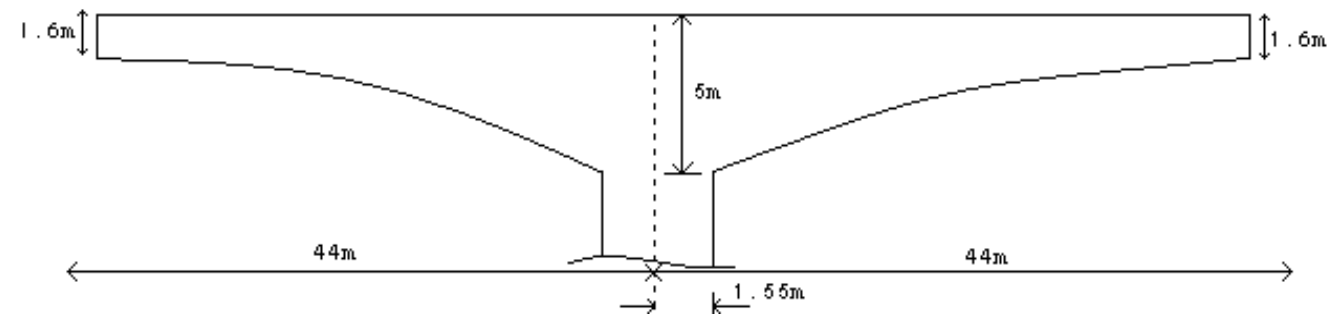

\subsection{Analysis}

Figure 11: Balanced cantilever of Shambat Bridge

Following similar procedure adopted for Burri Bridge, the corresponding long-term deflection values calculated for Shambat Bridge are obtained and summarized in Table 8.

Table 8: Final long-term deflections in Shambat Bridge (According to AASHTO-LRDF)

\begin{tabular}{|c|c|c|c|c|}
\hline $\begin{array}{c}\text { Distance, } \\
\boldsymbol{x} \text { from } \\
\text { support } \\
(\mathbf{m})\end{array}$ & $\begin{array}{c}\text { Dead load } \\
\text { deflection } \\
(\mathbf{m m})\end{array}$ & $\begin{array}{c}\text { Live load } \\
\text { deflection } \\
(\mathbf{m m})\end{array}$ & $\begin{array}{c}\text { Prestressing } \\
\text { deflection } \\
(\mathbf{m m})\end{array}$ & $\begin{array}{c}\text { Total deflection } \\
(\mathbf{m m})\end{array}$ \\
\hline 0 & 0.00 & 0.00 & 0.00 & 0.00 \\
\hline 8 & -15.36 & -2.63 & +9.80 & -8.20 \\
\hline 16 & -67.98 & -13.92 & +38.25 & -43.64 \\
\hline 24 & -158.24 & -39.08 & +85.99 & -111.33 \\
\hline 32 & -257.66 & -76.19 & +152.37 & -181.47 \\
\hline 42.7 & -310.42 & -102.41 & +194.78 & -218.05 \\
\hline
\end{tabular}




\subsection{Load Test Results of Shambat Bridge}

The same loading setup described in section 4.6 is used for Shambat Bridge. Table 9 summarizes the values of measured and calculated long-term deflection for the case of Shambat Bridge.

Table 9: Measured and calculated long-term deflections due to test load (Source: Shambat Bridge test report ${ }^{[12]}$ )

\begin{tabular}{|c|c|c|c|}
\hline Cross section & $\begin{array}{c}\text { Test point No. } \\
\text { (see Fig.10) }\end{array}$ & $\begin{array}{c}\text { Measured values } \\
\text { (mm) }\end{array}$ & $\begin{array}{c}\text { Calculated value } \\
\text { (mm) }\end{array}$ \\
\hline \multirow{4}{*}{ Cantilever end } & 9 & -186 & \multirow{2}{*}{-267} \\
\cline { 2 - 3 } & 10 & -99 & \multirow{2}{*}{-267} \\
\cline { 2 - 3 } & 11 & -179 & \\
\cline { 2 - 3 } & 12 & -126 & \\
\hline
\end{tabular}

\section{Discussion of the Results}

From the comparison of the deflections obtained from the test results with the calculated deflections, one can notice the following:

i. For Burri Bridge, the calculated deflections are smaller the measured ones by about $10 \%$.

ii. For Shambat Bridge, the calculated deflections are much higher than the measured ones.

The reason might be due to the assumptions regarding the theoretical parameters used in the calculations, e.g. $E_{\text {eff, }}$ (equation (17)), steel relaxation parameters, etc.

Also the reason might be perfect evidence of the test $\mathrm{H} / \mathrm{Y}$ load to the theoretical AASHTO H/Y load used in the computations.

\section{Conclusions}

The following conclusions have been drawn from this study:

i. The estimated long-term deflections (after 30 years for Burri Bridge ${ }^{[13]}$ and 40 years for Shambat Bridge) are found to be approximately 3-times short-term deflections.

ii. The long term deflections at the end of the cantilever of Burri Bridge as calculated theoretically are found to be greater than allowable measured 
deflections due to the Prestress losses. The existence of these high deflections may lead to the deterioration of the aesthetics of the bridge and may reach a level where serviceability and traffic safety are violated. Therefore, repair and rehabilitation of the bridge are essential.

iii. The comparison shows remarkable differences between theoretical and measured deflection values at the end of cantilevers. The differences are probably due to the basic assumptions made in the formulations of deflection calculations.

iv. Despite the difference between the calculated and measured deflection values, moment area method is found to be a suitable method for calculating long-term deflections in balanced cantilever bridges.

v. The stiffness of the bridges is highly affected by long-term deflection parameters which resulted in highly deflected cantilevers.

vi. Balanced cantilever post tensioned superstructure is not the ideal selection for long span bridges.

\section{References}

[1] Peter F. Takács, "Deformations in Concrete Cantilever Bridges" The Norwegian University of Science and Technology, Trondheim, Norway, March 2002.

[2] S.T.I.P.I Design Drawing Sheets of Burri Bridge and Shambat Bridge.

[3] Edward G, Nawy "Prestressed Concrete", Fourth Edition, 2003. University of California, USA.

[4] http://www.wsdot.wa.gov/fasc/EngineeringPublications, "Bridges Design Manual", Washington State Department of Transportation, September 2000.

[5] Lee, D. Kung, "Reinforced Concrete Bridges", Boca Raton Press, 2000.

[6] Wai-Fah Chen and Lian Duam, "Highway Bridge Loads and Load Distribution, CRC Press, 2000.

[7] Wai-Fah Chen and Lian Duam, "Prestressed Concrete Bridges", Boca Raton, CRC Press, 2000.

[8] American Concrete Institute, "Building Code Requirements for Structural Concrete and Commentary (ACI 2009M), 2003. 
[9] Ministry of Infrastructure, Khartoum State, "Test Report of Burri Bridge", 2005.

[10] Longjian Road and Bridge Co. Ltd.P.R.China. "Engineering Drawings for Maintenance and Repair of Burri Bridge, March, 2005.

[11] AASHTO-LRFD "Bridge Design Specifications, "Third Edition 2005.

[12] Longjian Road and Bridge Co. Ltd. P.R.China, "Test Report of Shambat Bridge", 2005.

[13] Mohamed Elmuntasir Albagir, "Deflection of Burri Bridge due to the Losses in Prestressed Concrete Bridges", a thesis submitted to the Faculty of Engineering - University of Khartoum in partial fulfillment of the requirements of the M.Sc. degree, 2008. 